\title{
人工海水環境下における各種ベントナイト の透水係数
}

\author{
小峯 秀雄 1 ・安原 一哉 2 ・村上 哲 3 \\ 1正会員 茨城大学教授 工学部都市システム工学科（テ316-8511 茨城県日立市中成沢町4-12-1） \\ E-mail: hkomine@mx.ibaraki.ac.jp \\ 2フェロー会員 茨城大学名誉教授 地球変動適応科学研究機関(ICAS) 産官学連携研究員 \\ （干310-8512 茨城県水戸市文京2-1-1） \\ 3正会員 茨城大学准教授 工学部都市システム工学科（テ316-8511 茨城県日立市中成沢町4-12-1）
}

\begin{abstract}
高レベル放射性廃棄物の地層処分施設は，廃棄体運搬の利便性等の観点から，沿岸域付近に建設される 可能性がある，その場合，処分施設に流入する地下水には海水起源の塩類が含まれることが予想される. そこで本研究では, 地層処分において最も重要な人工バリアであるベントナイト系緩衝材の仕様設計に資 するため, 各種ベントナイトの人工海水環境下での透水係数を実験的に調査した。 その結果に基づき, 低 透水性の観点から海水の影響を受けにくいベントナイトの種類や緩衝材の仕様を明らかにした. また, ベ ントナイトの透水係数に及ぼす海水中の陽イオンの影響について, 既往の研究成果に基づきモンモリロナ イト結晶層の濾過機能の観点から検討を行い，透水係数に及ぼす人工海水の影響メカニズムを考察した.
\end{abstract}

Key Words : high-level radioactive waste, bentonite, hydraulic conductivity, seawater

\section{1. はじめに}

高レベル放射性廃棄物の地層処分技術は，21 世紀 に確立されなければならない重要な技術的課題であ る. 我が国ならびに欧米各国で考えられている高レ ベル放射性廃棄物の有力な処分方法は, 地下数百 $\mathrm{m}$ より深い地盤中に, 収納容器に封入した廃棄物を埋 設処分する方法である ${ }^{1)-6)}$. この処分方法は，天然 の岩盤と人工的な隔壁の多重のバリアを構築し, 高 レベル放射性廃棄物を長期にわたって人間が関与し なくても安全に隔離できる方法とされている ${ }^{1), 21}$.

多重バリアの中の一つに廃棄体と周辺岩盤の隙間 を充填する「緩衝材」と呼称される材料がある. 緩 衝材には, 廃棄体一の地下水の接触を遅延すること, 施設施工上の制約により生じる隙間を充填すること 等が期待されている ${ }^{1)-3)}$. ベントナイトは, 他の土 質系材料と比べて低透水性であり，また水みちとな り得る緩衝材と周辺岩盤との隙間を膨潤変形により 充填し, 十分な低透水性を発揮することから「緩衝 材」としての利用が有望視されている ${ }^{1)-3) . ~}$

ところで, 高レベル放射性廃棄物の地層処分施設 は, 廃棄体運搬の利便性等の観点から沿岸域付近に 建設される可能性がある. 沿岸域付近における処分 施設建設を想定した場合，図-1 に示すように，処
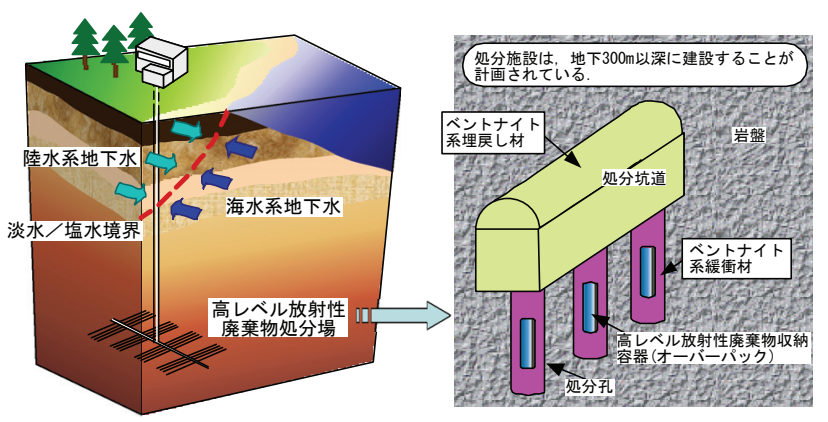

図-1＼cjkstart沿岸部に建設される高レベル放射性廃棄物処分施設 の概念図

分施設に流入してくる地下水には, 化石地下水や塩 水楔, 海水準変動等により海水起源の塩類が含有さ れると考えられる ${ }^{1)}$. 実際, 沿岸域付近の大深度地 下の地下水の化学組成が, 現在の海水の 1/2 1/3 程 度の塩分濃度を示したという事例 ${ }^{4)}$ も報告されてい る. ベントナイトの透水係数や膨潤特性は周辺の水 の性質等の周辺環境条件に大きく影響を受けること が知られている ${ }^{7)}$. ここ数年では, 高レベル放射性 廃棄物の地層処分を想定して, ベントナイトの膨潤 特性に及ぼす水質の影響についての研究が進められ ている ${ }^{8)-12)}$. また, ベントナイト系材料の透水係数 に対する水質の影響について, いくつかの研究成果 が報告されている ${ }^{13)-17)}$ 。しかし，一般・産業廃棄物 
処分施設のベントナイト系遮水材を想定した研究で は, 本研究で対象とするベントナイト系緩衝材と比 較すると, 低い乾燥密度でベントナイトの配合割合 も小さい条件での研究結果 14), 15), 17)である。また, 参考文献 16)では，高レベル放射性廃棄物を対象と しているが，ベントナイト系埋戻し材を対象として おり, 粉砕した花崗岩とベントナイトを質量比率で それぞれ $70 \%$ と $30 \%$ で混合した材料の研究成果であ る. 参考文献 13)では, 当該文献の著者らの取得し た人工海水環境下での透水係数データを報告すると 共に，透水現象をモデル化することを試みている.

以上のように, ベントナイト系材料の透水係数に 及ぼす水質の影響に関しても, 徐々に研究成果が報 告されているものの, 低透水性のベントナイトの透 水試験そのものが難しい試験であること, 加えて, 透水試験で使用寸る水溶液が高濃度のイオンを保有 する海水等であることから，さらなる実験データの 取得をす寸め, そのデータの再現性を確認すると共 に, より理論的な影響メカニズムの解明が必要と考 えられる。

本研究では, 高圧圧密試験装置を用いてベントナ イト系材料の透水係数を算出する方法 ${ }^{18)}$ に基づき, 高レベル放射性廃棄物地層処分施設周辺の地下水々 して陸水系および海水系地下水を想定して, 蒸留水 および人工海水環境下における各種ベントナイトの 透水係数データについて報告するとともに，その結 果に基づき，低透水性の観点から海水の影響を受け にくいベントナイトの種類や緩衝材の仕様を明らか にする.

また，ベントナイトの透水係数に及ぼす海水中の 陽イオンの影響について, 既往の研究成果 ${ }^{11), 12)}$ 基づきモンモリロナイト結晶層の濾過機能の観点か ら考察を行い, 透水係数に及ぼす人工海水の影響入 カニズムを明らかにする。

\section{2. 高圧圧密試験による各種ベントナイトの透 水係数の測定}

本章では, 高圧圧密試験による各種ベントナイト の透水係数の測定の概要について述べる. 具体的に は高圧圧密試験に使用するベントナイト試料, 供試 体作製方法, 高圧圧密試験の概要と手順, 透水係数 の算出方法および供給する水溶液について論じる.

各種ベントナイトの透水係数の測定において, 高 圧圧密試験による透水係数の測定の優位性は次の通 りである ${ }^{18)}$. 高圧圧密試験により透水係数を求める
表-1 各種ベントナイトの基本的性質

\begin{tabular}{|c|c|c|c|c|c|}
\hline ベントナイト & A & B & C & $\mathrm{D}$ & E \\
\hline タイプ & $\mathrm{Na}$ 型 & $\mathrm{Na}$ 型 & $\mathrm{Ca}$ 型 & $\begin{array}{l}\mathrm{Na} \text { 交 } \\
\text { 換型 }\end{array}$ & $\mathrm{Na}$ 型 \\
\hline $\begin{array}{c}\text { 土粒子密度 } \\
\left(\mathrm{Mg} / \mathrm{m}^{3}\right)\end{array}$ & 2.79 & 2.84 & 2.71 & 2.68 & 2.88 \\
\hline 液性限界(\%) & 458.1 & 565.0 & 128.7 & 453.3 & 437.3 \\
\hline 塑性限界(\%) & 23.7 & 47.2 & 38.4 & 42.1 & 38.0 \\
\hline 塑性指数 & 434.4 & 517.8 & 90.3 & 411.2 & 399.3 \\
\hline $\begin{array}{c}\text { モンモリロナイ } \\
\text { ト含有率(\%) }\end{array}$ & 57 & 71 & 84 & 71 & 80 \\
\hline $\begin{array}{c}\text { 陽イオン交換容 } \\
\text { 量(meq./g) }\end{array}$ & 0.971 & 1.054 & 0.795 & 1.035 & 1.348 \\
\hline $\begin{array}{c}\text { 交換性 Na } \\
\text { イオン量(meq./g) }\end{array}$ & 0.573 & 0.572 & 0.119 & 0.620 & 0.646 \\
\hline $\begin{array}{c}\text { 交換性 Ca } \\
\text { イオン量(meq./g) }\end{array}$ & 0.352 & 0.328 & 0.585 & 0.333 & 0.522 \\
\hline $\begin{array}{c}\text { 交換性 K } \\
\text { イオン量(meq./g) }\end{array}$ & 0.030 & 0.026 & 0.019 & 0.019 & 0.038 \\
\hline $\begin{array}{c}\text { 交換性 Mg } \\
\text { イオン量(meq./g) }\end{array}$ & 0.016 & 0.128 & 0.072 & 0.063 & 0.142 \\
\hline $\begin{array}{l}\text { 本試験での } \\
\text { 使用の有無 }\end{array}$ & 有 & 有 & 有 & 無 & 有 \\
\hline
\end{tabular}

表-2 蒸留水および人工海水環境下における高圧圧密試 験に供したベントナイト A, B, C, Eの初期含水比

\begin{tabular}{|c|c|c|c|c|c|}
\hline \multicolumn{2}{|c|}{ ベントナイト } & A & B & C & E \\
\hline \multirow{2}{*}{$\begin{array}{l}\text { 初期 } \\
\text { 含水 } \\
\text { 比(\%) }\end{array}$} & $\begin{array}{c}\text { 蒸留 } \\
\text { 水環 } \\
\text { 境 }\end{array}$ & $\begin{array}{c}6.73 \sim \\
7.09\end{array}$ & $\begin{array}{c}9.82 \sim \\
9.92\end{array}$ & 18.08 & $\begin{array}{c}12.40 \sim \\
12.73\end{array}$ \\
\hline & $\begin{array}{l}\text { 人工 } \\
\text { 海水 } \\
\text { 環境 }\end{array}$ & $\begin{array}{c}6.50 \sim \\
6.67\end{array}$ & 10.03 & 17.05 & 13.10 \\
\hline
\end{tabular}

際には, 圧密変位量を排水量として考えることがで き, 高分解能の変位計を用いることにより, ごく微 少な排水量の測定を精度良く実施できる。このこと から，メニスカスの影響が生じるビュレットを用い た排水量測定では透水係数の算出に年単位の試験期 間を要するベントナイト試料に対しても，おおよそ 10 日間の測定で透水係数を算出することができる ${ }^{18)}$.

\section{（1）使用した試料}

著者らの研究グループでは, 諸特性の異なる代表的 なベントナイトとして, 山形県月布産のベントナイト A（クニゲルV1・クニミネ工業），アメリカ・ワイオ ミング産のベントナイトB（ボルクレイ・日商岩井ベ ントナイト株式会社），宮城県土浮山鉱床産のベント ナイトC（クニボンド・クニミネ工業），宮城県川崎 町産のベントナイトD（ネオクニボンド・クニミネ工 業），およびアメリカ・ワイオミング産のベントナイ 卜E（MX-80・日商岩井ベントナイト株式会社）を選 定している ${ }^{8)}$. モンモリロナイト含有率と交換性陽イオ 
ンの種類・組成に差異が認められる点から，これらを 代表的なベントナイトと選定している.このうち本研 究では, 緩衝材の材料として最も有望視されているNa 型ベントナイトである $\mathrm{A}, \mathrm{B}, \mathrm{E}$ と，それとは基本的な性 質を異にするCa型のベントナイトCの 4 種類を使用した. 表-1に上述のベントナイトの基本的性質と本研究で の使用の有無について示す9).

上述の各ベントナイトは温度 $20 \pm 3^{\circ} \mathrm{C}$ の室内で保 存されており, 後述の蒸留水および人工海水環境下 で実施した各高圧圧密試験開始直前に初期含水比の 測定を行った。ベントナイト A, B, CおよびEの初期 含水比は，表-2に示寸通りであった。ベントナイト Aは，日本の高レベル放射性廃棄物処分技術に関す る研究・開発において, 頻繁に試験等に利用されて いるベントナイトである。また， ベントナイトEは スウェーデンやスイス等における緩衝材の基本材料 とされている. ベントナイトBは，アメリカ・ワイ オミング産の Na型ベントナイトであり，AやEと異 なるモンモリロナイト含有率であることから試料と して使用した。一方，ベントナイトDはNa交換型ベ ントナイトである。このベントナイトも選定してい る理由は，欧州などCa型ベントナイトが多く産出さ れる地域において，それを $\mathrm{Na}$ 型に交換して使用する 可能性もあるからである。しかし， Na交換型ベント ナイトは, 水質の変化により膨潤特性が大きく変化 寸る可能性があるという実験結果 ${ }^{8)}$, 9) が得られてお り, 日本のように処分施設の周辺が海水環境になる ことが想定される場合には，使用は困難と考えられ ることから, 本研究では試料として用いなかった。

\section{（2）供試体作製方法}

前述のベントナイトA，B，CおよびEを用い，締固め た供試体を作製した。供試体は円柱型とし直径 $60 \mathrm{~mm}$ ，高さ $10 \mathrm{~mm}$ 目標として作製した．日本工業 規格「土の段階載荷による圧密試験方法(JIS A 1217:2009)」 ${ }^{19)}$ において，供試体の高さは20mmと規 定されている. しかし，ベントナイトは非常に低透 水性であるため供試体の飽和に長時間を要すること から供試体高さを小さくし, 供試体飽和時間の短縮 を図った。一方，供試体高さを小さくしすぎると， 圧密量一時間曲線における一次圧密領域が小さくな り， $\sqrt{t}$ 法の適用が困難となる。これに起因して圧 密係数の測定精度が低下し, 透水係数の算出におい て，信頼性が低くなることが予想される．著者らの 既往の研究 ${ }^{18)}$ では, 一次圧密領域が十分な精度を有 して確認でき, かつ供試体の飽和時間を短縮するこ とが可能な供試体高さとして10mmを採用しており，
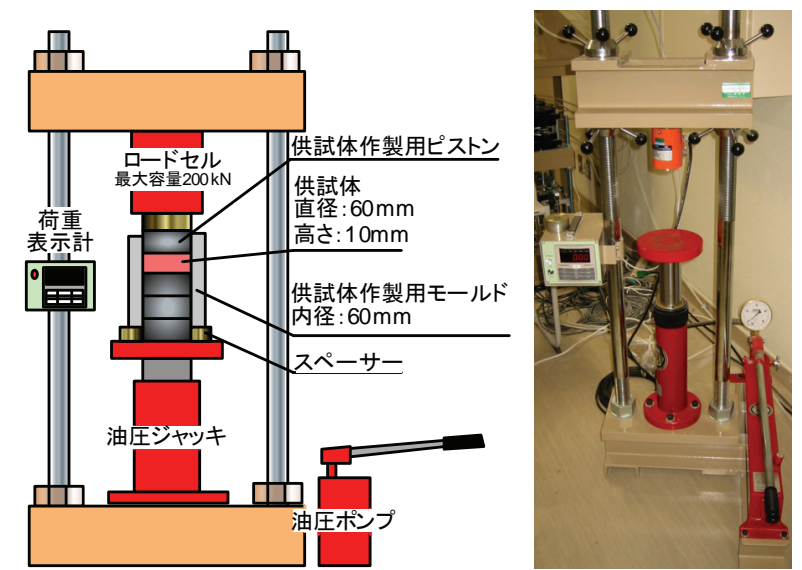

図-2 供試体作製装置（左：概略図，右：写真）

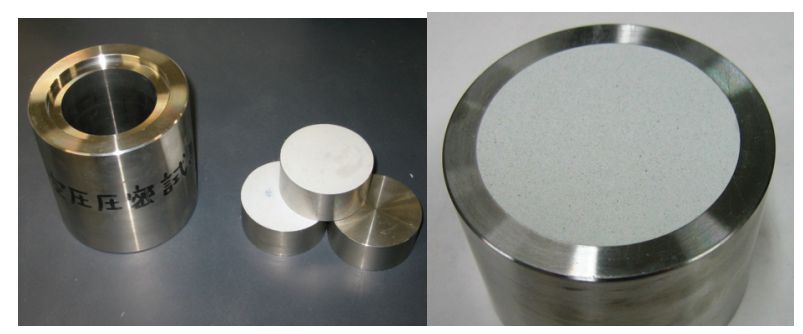

図-3 供試体作製用モールド・ピストン（左）と SUS316L ステンレス製リング内の供試体（右）

前述の通り, 本研究においても供試体高さを $10 \mathrm{~mm}$ とした。締固め荷重の載荷方法は，実際の緩衝材製 作においても金型モールドを用いた静的荷重による 作製方法が考えられていることから静的載荷を採用 した.

供試体作製装置は，最大荷重200kNの締固め圧力 載荷用油圧ジャッキ, 反カフレームおよびロードセ ルからなる締固め装置と試料を投入する内径 $60 \mathrm{~mm}$, 外径 $80 \mathrm{~mm}$, 高さ $100 \mathrm{~mm}$ の鋼製円筒形の供試体作製 用モールドおよびピストンで構成される. 図-2に, 供試体作製装置の概略図と写真を示寸。供試体作製 手順は以下の通りである. 図-3左に示す供試体作製 用モールド内に, 締固めた後の供試体高さが約 $10 \mathrm{~mm}$ になるように, 後述の表-8に示寸目標乾燥密 度に対応して所定質量の試料を投入し, 試料の上下 にピストンをセットした（図-2左の概略図を参照）。 さらに，供試体作製用モールドの下部に，図-2左の 概略図に示すようにスペーサーを挿入し，モールド 中央部に投入試料が位置するようにした。 その後, モールドを供試体作製装置に移動し，油圧ジャッキ を用いて試料に，15～140kNの範囲で一定の締固め 圧力を作用させ15分間放置した。 なお，締固め圧力 載荷直後に試料の上下端へ圧力を作用させるため, スペーサーを抜き取った，締固め圧力は，ピストン 部に設置されたロードセルにより計測した．15分経 


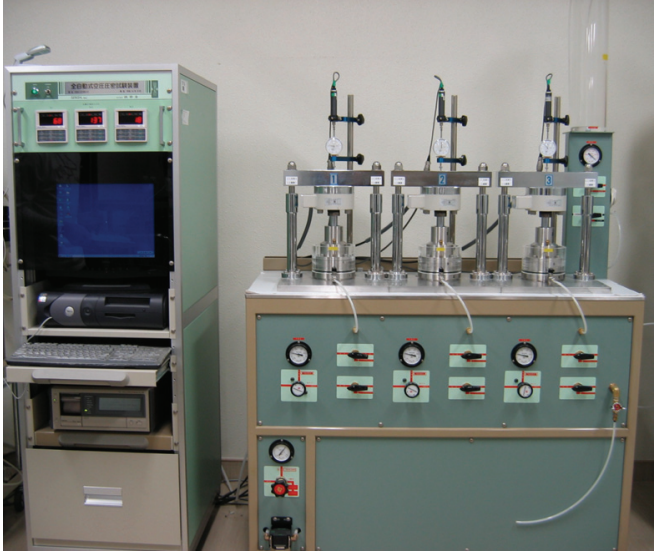

図-4 高圧圧密試験装置（左 : 全体写真，右 : 拡大写真)

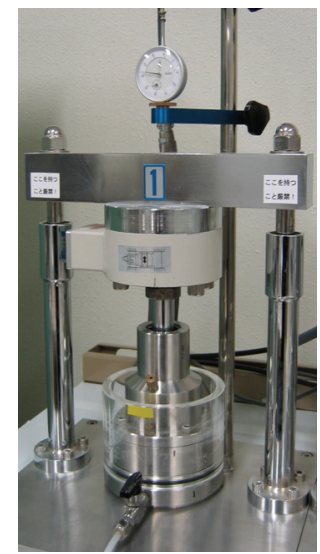

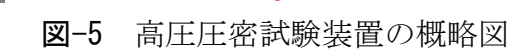

\begin{tabular}{|c|c|} 
表-3 メンブレンフィルター物性值 \\
\hline 項目 & 物性值 \\
\hline 直径 $(\mathrm{mm})$ & 60.0 \\
\hline 厚さ $(\mathrm{mm})$ & 0.025 \\
\hline 最大孔径 $(\mu \mathrm{m})$ & $0.075 \sim 0.25$ \\
\hline 密度 $\left(\mathrm{Mg} / \mathrm{m}^{3}\right)$ & 0.49 \\
\hline ポアソン比 & 0.50 \\
\hline
\end{tabular}

過後，専用の抜き取り装置を用い，供試体をモール ドから高圧圧密試験用圧密容器のSUS316Lステンレ ス製リングの下部に移動させた。最後に，供試体高 さが10mmになるようSUS316Lステンレス製リング からはみ出た試料を整形し供試体作製を完了とした

（図-3右を参照）。なお，ピストンの外径は，供試 体作製用モールドの内径より 0.05mm小さしてお り，ピストンとモールドの間に摩擦は生じない。

\section{(3) 高圧圧密試験の概要と手順}

図-4 および図-5 に, 本研究で使用した高圧圧密 試験装置の写真と概略図を示寸。本試験装置は, 空 圧ベロフラムシリンダを 2 段使用し，パーソナルコ

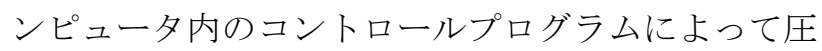
密圧力を制御し, 電磁弁を用いることで加圧, 圧力 維持および減圧を制御できるものである。これによ り, 載荷段階の移行における加圧および減圧に際し て発生する計測時間のタイムラグを抑えることがで きる，使用した高圧圧密試験装置は，供試体の直径 が $60 \mathrm{~mm}$ のとき, 最大圧密圧力として $10 \mathrm{MPa}$ を作 用させることができる.

高圧圧密試験の結果から比較的精度良く透水係数 を算出するためには，圧密量一経過時間の関係を滑 らかな曲線で描くことのできるよう細かい計測時間 ごとに圧密量のデータを記録する必要がある。そこ で本研究では, 各載荷段階において, 各圧密圧力を 作用させた後 20 分間は 15 秒間隔で 80 回, 120 分ま では 10 分間隔で 10 回, 720 分までは 60 分間隔で
表-4 人工海水の主な化学成分

(20L 当たり，メーカー仕様書による)

\begin{tabular}{|c|c||c|c|}
\hline $\mathrm{MgCl}_{2}$ & $222.30 \mathrm{~g}$ & $\mathrm{KBr}$ & $2.01 \mathrm{~g}$ \\
\hline $\mathrm{CaCl}_{2}$ & $30.70 \mathrm{~g}$ & $\mathrm{H}_{3} \mathrm{BO}_{3}$ & $0.54 \mathrm{~g}$ \\
\hline $\mathrm{SrCl}_{2}$ & $0.85 \mathrm{~g}$ & $\mathrm{NaF}$ & $0.06 \mathrm{~g}$ \\
\hline $\mathrm{KCL}$ & $13.89 \mathrm{~g}$ & $\mathrm{Na}_{2} \mathrm{SO}_{4}$ & $81.88 \mathrm{~g}$ \\
\hline $\mathrm{NaHCO}_{3}$ & $4.02 \mathrm{~g}$ & $\mathrm{NaCl}$ & $490.90 \mathrm{~g}$ \\
\hline
\end{tabular}

表-5 使用した人工海水の主要な陽イオン濃度

\begin{tabular}{|c|c|c|c|}
\hline \multicolumn{4}{|c|}{ 各陽イオン濃度 $\left(\mathrm{mol} / \mathrm{m}^{3}\right)$} \\
\hline $\mathrm{Na}$ イオン & Caイオン & $\mathrm{Mg}$ イオン & Kイオン \\
\hline 454.4 & 6.2 & 50.0 & 9.0 \\
\hline
\end{tabular}
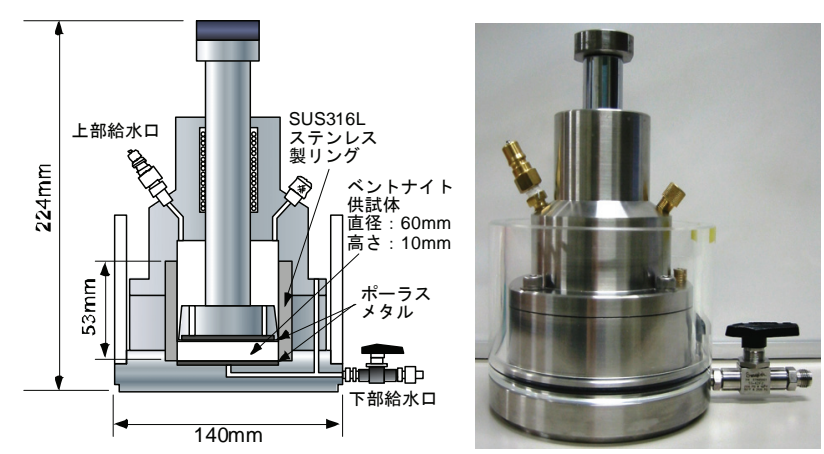

図-6 圧密容器の詳細図（左 : 詳細図, 右 : 写真)

10 回，1440 分までは 180 分間隔で 4 回経時的に圧 密量のデータを測定した。また，各ステップの載荷 時間は 24 時間とし, 本試験に用いた変位計（東京 測器研究所製 CDP-10, 定格出力 $10000 \times 10^{-6}$ ひずみ $\pm 0.1 \%$ ）の最大容量は $10 \mathrm{~mm}$, 最小目盛は 1/1000mm のものとした。本高圧圧密試験を実施し

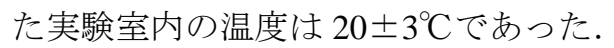

試験手順の詳細を以下に示す。まず，ピストンと SUS316L ステンレス製リング壁面との間に生じるで あろう摩擦を低減するため, 摩擦低減用シリコング リスをリング壁面に塗布した。供試体上下端部に設 置したポーラスメタルへのベントナイト粒子の侵入 
を防ぐため，供試体の上下に親水性ポリプロピレン 製のメンブレンフィルターを敷設した。表-3 に使 用したメンブレンフィルターの諸元を示す．その後, SUS316L ステンレス製リングとともに供試体を底板 の上に設置し, 図-6 に示すように圧密容器を組み 立て, 図-4 右および図-5 に示すように高圧圧密試 験装置に設置した.

その後, 図-6 に示寸圧密容器の上部および下部 に取り付けられた給水口に給水チューブを取り付け, 圧密量および圧密圧力の測定を開始すると同時に, 供試体一の給水を供試体上下から開始し, 前述の設 定された時間ごとに圧密量の計測を行った．圧密試 験中は，圧密容器内の水位を一定に保ち続けるよう に水溶液を随時供給した。試験終了後, 圧密容器を 解体し, 供試体の含水比測定, 圧密リング内の水溶 液の採取を行った。

供試体に供給する水溶液には，蒸留水および人工 海水（八洲薬品（株）製・アクアマリン, 表-4 参 照）を用いた。表-5 にイオンクロマトグラフィに より測定した人工海水の主要な陽イオン濃度の測定 結果を示す。

\section{（4）高圧圧密試験の結果の整理と透水係数の算出方法}

前述の手順で取得された圧密データを，日本工業 規格「土の段階載荷による圧密試験方法(JIS A 1217:2009)」に準拠し，結果の整理を行った。圧密 量と時間の関係は国内外で多用されている $\sqrt{t}$ 法に より整理した。各載荷段階において圧密係数 $c_{v}$ $\left(\mathrm{m}^{2} / \mathrm{sec}\right)$, 体積圧縮係数 $m_{v}\left(\mathrm{~m}^{2} / \mathrm{kN}\right)$ を求め, 式(1)によ り透水係数 $k(\mathrm{~m} / \mathrm{sec})$ を算出した.

$$
k=c_{v} m_{v} \rho_{w} g(\mathrm{~m} / \mathrm{sec})
$$

ここに, $\rho_{w}$ : 水の密度 $\left(\mathrm{kN} \cdot \mathrm{sec}^{2} / \mathrm{m}^{4}\right), g$ : 重力加速 度 $\left(=9.80665 \mathrm{~m} / \mathrm{sec}^{2}\right)$

圧密試験から透水係数を算出できる前提条件とし て，供試体が飽和していることが挙げられる，著者 らの既往研究 ${ }^{18)}$ において，本試験の条件で，供試体 の飽和度を確認する試験を行った。すなわち, 各種 ベントナイトの供試体を作製し，高圧圧密試験を開 始し試験開始から2日および3日経過後, 試験を終了 して供試体を取り出し, その含水比の測定を行い, 飽和度を算出した。供試体を試験装置から取り出す 際は，圧密圧力を除荷し直ちに圧密容器を解体し供 試体をリングから取り外すのであるが，その際，供 試体がリング内の蒸留水を上部より給水し, 膨張す

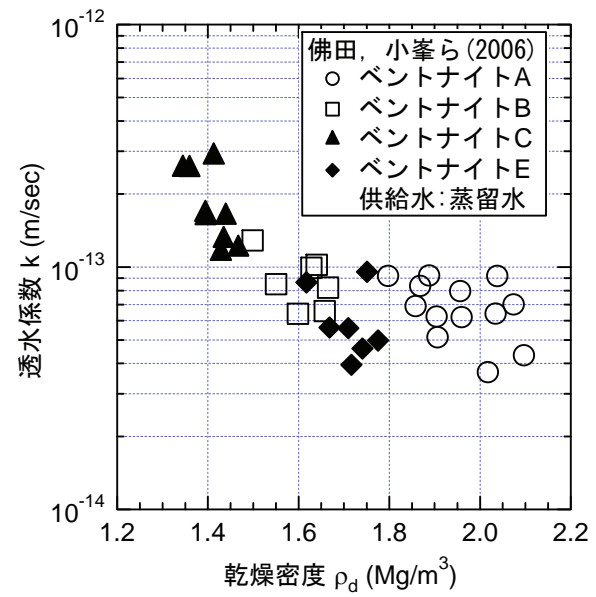

図-7 参考文献 18)で報告された各種ベントナイトの 透水係数と乾燥密度の関係

ると考えられるので，飽和度算出の際には供試体を 上下に分割し，その下部から求めた含水比を採用し た。その結果によれば, ベントナイトの種類によら ず，給水開始から2日間でほぼ飽和すると判断され た。そこで本試験においても供試体の飽和期間を2 日間とし, 圧密データの整理は, 供試体が飽和する と考えられる3日目, 寸なわち圧密圧力が3ステップ 以降の測定結果に基づいて行うこととした.

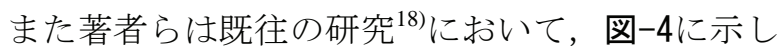
た最大圧密圧力 $10 \mathrm{MPa}$ の高圧圧密試験装置を用いて, より信頼性の高い透水係数の算出ができるように試 験方法の高度化を行った。具体的には, 試験に用い る変位計を最小目盛 $1 / 1000 \mathrm{~mm}$ の分解能のものにす ること，および測定に際して各圧密圧力を作用させ てから20分間における測定データ数を80に増やすこ と, また, 圧密圧力5.88MPa以上で15秒経過時点で の沈下量が全沈下量の $30 \%$ 以下となっている実験デ 一タであれば， $\sqrt{t}$ 法による圧密量一時間曲線の初 期直線部分を明瞭に把握することが可能となり，再 現性の高い透水係数の算出が可能であることを実験 的に明らかにした。本研究においても, 参考文献 18)に提案した試験方法に準拠して実施した。提案 した試験方法の妥当性については，参考文献18)を 参照されたい.

\section{3. 広範囲な乾燥密度における各種ベントナイ 卜の透水係数}

本研究の主題は, 図-4に示す高圧圧密試験装置を 利用して，蒸留水および人工海水環境下における各 種ベントナイトの透水係数データについて実験的に 調査すると共に, 海水の影響について考察すること 
である．蒸留水環境における各種ベントナイトの透 水係数については，参考文献18)において，高圧圧 密試験により得られた透水係数データを報告した。

図-7に，その結果を示す。しかし，高い圧密圧力を 作用させた条件で得られた透水係数データであるた め, 図-7から分かるように, 各ベントナイトとも乾 燥密度が比較的狭い範囲に限定された。ベントナイ 卜系緩衝材の乾燥密度は, $1.4 \sim 2.0 \mathrm{Mg} / \mathrm{m}^{3}$ 程度が考

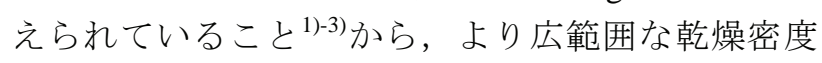
における透水係数データの取得が必要である。 そこ で本研究ではまずはじめに, 比較的広範囲の乾燥密 度条件下でのベントナイトの透水係数データ取得が 可能な高圧圧密試験における圧密圧力条件々, 各種 ベントナイトの透水係数と乾燥密度の関係について 調查する。その際には，参考文献18)に報告した図一 7の実験データも併用して考察する.

\section{（1）圧密圧力の設定}

ベントナイト系緩衝材の乾燥密度としては, 1.4 $\sim 2.0 \mathrm{Mg} / \mathrm{m}^{3}$ 程度が考えられていることから，この範 囲の乾燥密度における透水係数の測定が実施できる ように, 高圧圧密試験における最小圧密圧力, 最大 圧密圧力および段階載荷における各ステップでの圧 密圧力増分を表-6のように設定した. 表-6に示寸よ

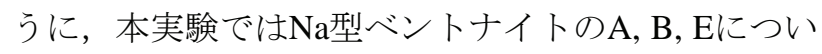
て, より広範囲の乾燥密度における透水係数を測定 した。一方, Ca型ベントナイトCの場合は，その締 固め特性 ${ }^{20)}$ の観点から, 元来締まりにくい性質を有 する材料であり, $1.5 \mathrm{Mg} / \mathrm{m}^{3}$ 以上の乾燥密度に締固め ることは困難である。したがって, ベントナイトC については，参考文献18)および図-7に示した実験 データを活用することとし, より広範囲の乾燥密度 における透水係数の測定は, 特に実施しなかった. なお，表-6に示した条件設定に際しては，各種ベン トナイトの乾燥密度に応じた膨潤圧の值を既往の研 究成果 ${ }^{9)}$ に基づいて予想し, 圧密圧力の設定を行っ た。実際には，供試体の飽和期間に当てた 1 2ステ ップの載荷段階において, 供試体が膨潤変形したケ 一スもあり, 初期乾燥密度よりも低い乾燥密度の透 水係数のデータが測定される場合もあった.

\section{（2）広範囲な乾燥密度における各種ベントナイトの 透水係数とその傾向}

図-8 に表-6 に示寸試験条件 A-1 における圧密変 位量と経過時間の関係を例示する。なお，図-8 は， 前章で述べた通り，供試体がほぼ飽和したと考えら れる 3 ステップ以降の結果を示した。また, 図中の
表-6 本研究で新たに実施した蒸留水環境下における 高圧圧密試験の圧密圧力条件

\begin{tabular}{|c|c|c|c|c|c|c|}
\hline $\begin{array}{l}\text { ベ } \\
\text { ン } \\
\text { ト } \\
\text { ナ } \\
\text { イ } \\
\text { ト }\end{array}$ & $\begin{array}{l}\text { 試 } \\
\text { 験 } \\
\text { 条 } \\
\text { 件 }\end{array}$ & $\begin{array}{l}\text { 初期乾 } \\
\text { 燥密度 } \\
\left(\mathrm{Mg} / \mathrm{m}^{3}\right)\end{array}$ & $\begin{array}{c}\text { 最小圧 } \\
\text { 密圧力 } \\
\text { の目標 } \\
\text { 值 (MPa) }\end{array}$ & $\begin{array}{c}\text { 最大圧 } \\
\text { 密圧力 } \\
\text { の目標 } \\
\text { 值 } \\
\text { (MPa) }\end{array}$ & $\begin{array}{l}\text { 圧密 } \\
\text { 圧力 } \\
\text { 増分 } \\
(\mathrm{MPa})\end{array}$ & $\begin{array}{l}\text { 荷 } \\
\text { 重 } \\
\text { 段 } \\
\text { 階 } \\
\text { 総 } \\
\text { 数 }\end{array}$ \\
\hline \multirow{5}{*}{ A } & A-1 & 1.567 & 1.96 & 9.80 & 1.96 & 5 \\
\hline & A-2 & 1.457 & 0.98 & 4.90 & 0.98 & 5 \\
\hline & A-3 & 1.555 & 1.96 & 9.80 & 1.96 & 5 \\
\hline & A-4 & 1.415 & 0.98 & 4.90 & 0.49 & 9 \\
\hline & A-5 & 1.430 & 1.96 & 9.80 & 0.98 & 9 \\
\hline \multirow{5}{*}{ B } & B-1 & 1.406 & 1.47 & 4.90 & 0.49 & 8 \\
\hline & B-2 & 1.703 & 4.90 & 8.82 & 0.49 & 9 \\
\hline & B-3 & 1.702 & 3.92 & 7.84 & 0.49 & 9 \\
\hline & B-4 & 1.601 & 5.39 & 9.31 & 0.49 & 9 \\
\hline & B-5 & 1.524 & 5.88 & 9.80 & 0.49 & 9 \\
\hline \multirow{7}{*}{$\mathrm{E}$} & E-1 & 1.476 & 2.94 & 6.86 & 0.49 & 9 \\
\hline & E-2 & 1.484 & 2.94 & 9.80 & 0.98 & 8 \\
\hline & E-3 & 1.673 & 3.92 & 7.84 & 0.49 & 9 \\
\hline & E-4 & 1.457 & 1.47 & 4.90 & 0.49 & 8 \\
\hline & E-5 & 1.476 & 0.98 & 4.41 & 0.49 & 8 \\
\hline & E-6 & 1.762 & 3.92 & 7.84 & 0.49 & 9 \\
\hline & E-7 & 1.778 & 5.39 & 9.31 & 0.49 & 9 \\
\hline
\end{tabular}

圧密圧力 $\sigma_{\mathrm{v}}$ の值は, 各ステップにおいて高圧圧密試 験装置のロードセルで測定された圧密荷重の平均值 から算出した圧密圧力である. 図-8 から分かるよ うに, 既往研究 18)に提案した試験方法によれば, $\sqrt{t}$ 法による圧密量一時間曲線が滑らかに描かれ, 初期直線部分を明瞭に把握でき, $t_{90}$ や $d_{90}$ の值が求 められることが分かる.これらの圧密変位量と経過 時間の関係から求められる圧密特性データの例とし て, 表-7 に試験条件 A-1 のデータを示す.なお, 表-7 中の乾燥密度は, 各圧密ステップにおける乾 燥密度の平均值である.

これと同様にして，表-6 に示寸実験条件で高圧 圧密試験を行い, 広範囲な乾燥密度における各ベン トナイトの透水係数の測定を実施した.

表-8 には, 本研究における透水係数データ測定 時の乾燥密度の範囲を示寸. 各ベントナイトにおい て，それぞれ目標とする乾燥密度の範囲をおおよそ 網羅していることが分かる. なお，透水係数を算出 する際の各載荷段階において, ベントナイト供試体 の膨潤変形は生じていないことを確認している.

図-9 は, 本研究で新たに取得した透水係数デー 夕と, 佛田ら ${ }^{18)}$ において報告された透水係数データ とを併せ, 各種ベントナイトの透水係数と乾燥密度 の関係を示した。ここで述べる乾燥密度も, 各圧密 ステップにおける乾燥密度の平均值である.

図-9 より，連続性があり，より広範囲な乾燥密 

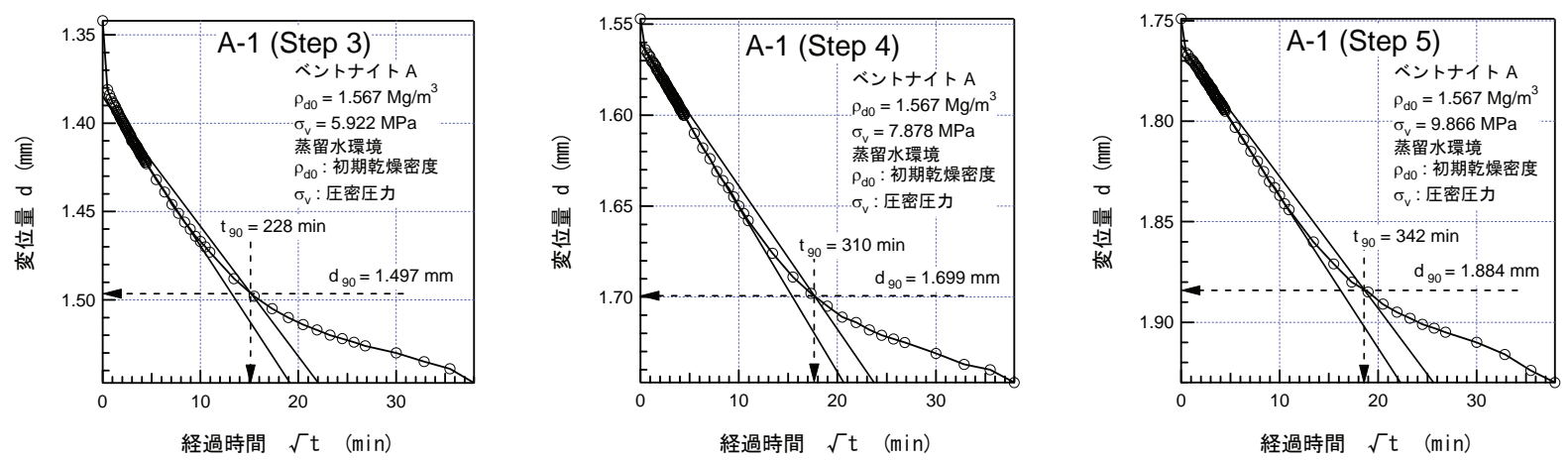

左 : 3 ステップ目, 中央 : 4 ステップ目, 右 : 5 ステップ目

図-8 試験条件 A-1 における圧密変位量と経過時間の関係

表-7＼cjkstart試験条件 A-1 における圧密特性データ

\begin{tabular}{|c|c|c|c|c|c|c|c|}
\hline $\begin{array}{c}\text { 試験条 } \\
\text { 件 }\end{array}$ & $\begin{array}{c}\text { 圧密 } \\
\text { ステップ }\end{array}$ & $\begin{array}{c}\text { 圧密圧力 } \\
(\mathrm{MPa})\end{array}$ & $\begin{array}{c}\text { 圧密量 } \\
(\mathrm{mm})\end{array}$ & $\begin{array}{c}\text { 乾燥密度 } \\
\left(\mathrm{Mg} / \mathrm{m}^{3}\right)\end{array}$ & $\begin{array}{c}\text { 圧密係数 } \\
\left(\mathrm{cm}^{2} / \mathrm{day}\right)\end{array}$ & $\begin{array}{c}\text { 体積圧縮係数 } \\
\left(\mathrm{m}^{2} / \mathrm{kPa}\right)\end{array}$ & $\begin{array}{c}\text { 透水係数 } \\
(\mathrm{m} / \mathrm{sec})\end{array}$ \\
\hline \multirow{3}{*}{$\mathrm{A}-1$} & 3 & 5.922 & 0.207 & 1.772 & 0.932 & $3.130 \times 10^{-5}$ & $3.312 \times 10^{-13}$ \\
\cline { 2 - 9 } & 4 & 7.878 & 0.200 & 1.851 & 0.627 & $1.326 \times 10^{-5}$ & $9.443 \times 10^{-14}$ \\
\cline { 2 - 9 } & 5 & 9.866 & 0.183 & 1.900 & 0.540 & $1.294 \times 10^{-5}$ & $7.929 \times 10^{-14}$ \\
\hline
\end{tabular}
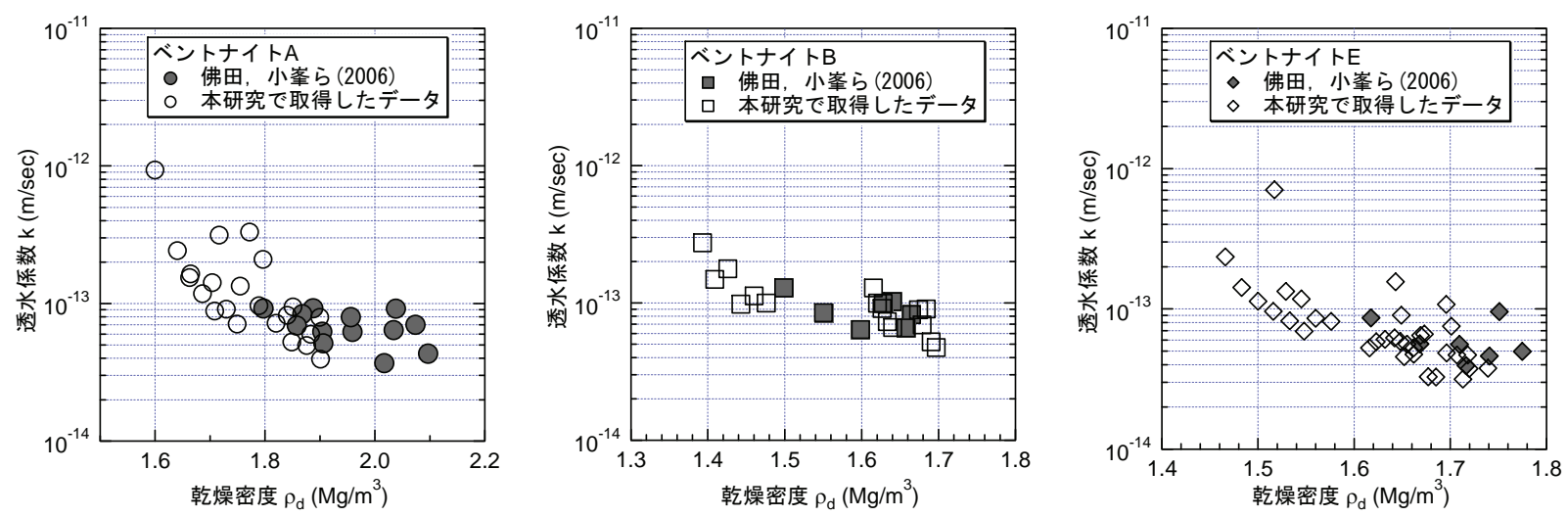

図-9 広範囲な乾燥密度におけるベントナイト $\mathrm{A}, \mathrm{B}, \mathrm{E}$ の透水係数

度の範囲における各種ベントナイトの透水係数が, 表-6 に示した圧密圧力条件により得られたことが 分かる.

図-9 の各種ベントナイトの透水係数と乾燥密度 の関係から，次のことが明らかとなった。すなわち，

1）ベントナイト A（Na 型，クニゲル V1）におい ては，乾燥密度が $1.8 〜 2.1 \mathrm{Mg} / \mathrm{m}^{3}$ の範囲におい て，10 $10^{-13} \mathrm{~m} / \mathrm{sec}$ 以下の透水係数が保持されている. 乾燥密度が $1.8 \mathrm{Mg} / \mathrm{m}^{3}$ よりも低い乾燥密度の範囲 で透水係数が増加しやすい傾向にある。

2) ベントナイト B ( $\mathrm{Na}$ 型, ボルクレイ）では, 乾 燥密度が $1.45 \sim 1.70 \mathrm{Mg} / \mathrm{m}^{3}$ の範囲において，お おむね $10^{-13} \mathrm{~m} / \mathrm{sec}$ 程度もしくはそれ以下の透水 係数が保持されている. 乾燥密度が $1.45 \mathrm{Mg} / \mathrm{m}^{3}$ よりも低い乾燥密度の範囲で透水係数がやや増 加しやすい傾向にある.

3) ベントナイト E (Na 型, MX-80) においては,
表-8 本研究で新たに取得した透水係数データの 測定時の乾燥密度の範囲

\begin{tabular}{|c|c|c|}
\hline $\begin{array}{c}\text { ベントナ } \\
\text { イト }\end{array}$ & $\begin{array}{c}\text { 目標の乾燥密度 } \\
\text { の範囲 }\end{array}$ & $\begin{array}{c}\text { 実際の試験時の } \\
\text { 乾燥密度の範囲 }\end{array}$ \\
\hline $\mathrm{A}$ & $1.4 \sim 1.8 \mathrm{Mg} / \mathrm{m}^{3}$ & $1.60 \sim 1.90 \mathrm{Mg} / \mathrm{m}^{3}$ \\
\hline $\mathrm{B}$ & $1.4 \sim 1.5 \mathrm{Mg} / \mathrm{m}^{3}$ & $1.39 \sim 1.70 \mathrm{Mg} / \mathrm{m}^{3}$ \\
\hline $\mathrm{E}$ & $1.4 \sim 1.7 \mathrm{Mg} / \mathrm{m}^{3}$ & $1.47 \sim 1.74 \mathrm{Mg} / \mathrm{m}^{3}$ \\
\hline
\end{tabular}

乾燥密度が $1.6 〜 1.8 \mathrm{Mg} / \mathrm{m}^{3}$ の範囲において，お おむね $10^{-13} \mathrm{~m} / \mathrm{sec}$ 程度もしくはそれ以下の透水 係数が保持されている. 乾燥密度が $1.6 \mathrm{Mg} / \mathrm{m}^{3}$ よ りも低い乾燥密度の範囲で透水係数が増加しや すい傾向にある。

以上の考察と図-8 の実験結果は, ベントナイト 系緩衝材の設計・製作において, 要求される透水係 数の観点から, 使用可能なベントナイトの種類の選 定に活用できると共に，選定したベントナイトに対 して, 緩衝材として要求される透水係数を達成する ための乾燥密度の設計に利用できる基礎データとな 
り得る。また, 著者らが提案している, 高圧圧密試 験装置を用いたベントナイトの透水係数の測定方法 の有効性を示すものでもある。非常に長い時間を要 するベントナイト系緩衝材の透水係数測定において, 比較的短時間で測定が可能な方法として，実際のプ ロジェクトにおいて活用できる試験方法と言える。

表-9 人工海水環境下における各種ベントナイトの高圧 圧密試験の圧密圧力条件

\begin{tabular}{|c|c|c|c|c|c|c|}
\hline $\begin{array}{l}\text { ベ } \\
\text { ン } \\
ト \\
+ \\
\text { ナ } \\
\text { ト }\end{array}$ & $\begin{array}{l}\text { 試験 } \\
\text { 条件 }\end{array}$ & $\begin{array}{c}\text { 初期乾燥 } \\
\text { 密度 } \\
\left(\mathrm{Mg} / \mathrm{m}^{3}\right)\end{array}$ & $\begin{array}{c}\text { 最小压 } \\
\text { 密圧力 } \\
\text { 目標 } \\
\text { 值 } \\
\text { (MPa) }\end{array}$ & $\begin{array}{c}\text { 最大压 } \\
\text { 密圧力 } \\
\text { 目標 } \\
\text { 值 } \\
(\mathrm{MPa})\end{array}$ & $\begin{array}{l}\text { 圧密圧 } \\
\text { 力増分 } \\
(\mathrm{MPa})\end{array}$ & $\begin{array}{l}\text { 荷 } \\
\text { 重 } \\
\text { 段 } \\
\text { 階 } \\
\text { 総 } \\
\text { 数 }\end{array}$ \\
\hline \multirow{7}{*}{ A } & A-1S & 1.564 & 1.96 & 9.80 & 1.96 & 5 \\
\hline & A-2S & 1.517 & 1.96 & 9.80 & 1.96 & 5 \\
\hline & A-3S & 1.408 & 0.98 & 4.90 & 0.49 & 9 \\
\hline & A-4S & 1.400 & 0.98 & 8.82 & 0.98 & 9 \\
\hline & A-5S & 1.970 & 1.96 & 9.80 & 1.96 & 5 \\
\hline & A-6S & 1.734 & 1.96 & 9.80 & .96 & 5 \\
\hline & A-7S & 1.549 & 1.96 & 9.80 & 1.96 & 5 \\
\hline \multirow{3}{*}{ B } & B-1S & 1.507 & 1.96 & 9.80 & 1.96 & 5 \\
\hline & B-2S & 1.399 & 1.47 & 9.31 & 0.98 & 9 \\
\hline & B-3S & 1.399 & 1.47 & 5.39 & 0.49 & 9 \\
\hline \multirow{3}{*}{ C } & C-1S & 1.548 & 1.96 & 9.80 & 1.96 & 5 \\
\hline & C-2S & 1.340 & 1.96 & 9.80 & 1.96 & 5 \\
\hline & C-3S & 1.190 & 1.96 & 9.80 & 1.96 & 5 \\
\hline \multirow{3}{*}{ E } & E-1S & 1.456 & 1.47 & 4.90 & 0.49 & 8 \\
\hline & E-2S & 1.453 & 2.45 & 5.88 & 0.49 & 8 \\
\hline & E-3S & 1.432 & 2.94 & 9.80 & 0.98 & 8 \\
\hline
\end{tabular}

\section{4. 人工海水環境下における各種ベントナイト の透水係数}

本章では，高レベル放射性廃棄物処分施設周辺の 地下水として海水系地下水を想定した各種ベントナ イトの透水係数のデータについて論ずるとともに， 蒸留水環境における透水係数と比較検討することに より，低透水性の観点から海水の影響を受けにくい ベントナイトの種類や緩衝材の仕様を明らかにする.

\section{（1）圧密圧力の設定}

表-9は，今回実施した人工海水環境下における各 種ベントナイトの高圧圧密試験の圧密圧力条件を示 す。これらの圧密圧力条件は，表-6に示した蒸留水 環境下における高圧圧密試験の圧密圧力条件と同様 に，比較的広範囲の乾燥密度における透水係数が測 定できるように設定した。

\section{（2）人工海水環境下における各種ベントナイトの透 水係数とその傾向}

図-10に，表-9に示す試験条件A-1S の圧密変位量 と経過時間の関係を例示する。図-10についても, 図-8に示した蒸留水環境下の実験と同様に，供試体 がほぼ飽和したと考えられる3ステップ以降の結果 を示した。また，図中の圧密圧力 $\sigma_{\mathrm{v}}$ の值は，各ステ ップにおいて高圧圧密試験装置のロードセルで測定 された圧密荷重の平均值から算出した圧密圧力であ る。図-10から分かるように，人工海水環境下の高 圧圧密試験であっても，本研究で採用した前述の試
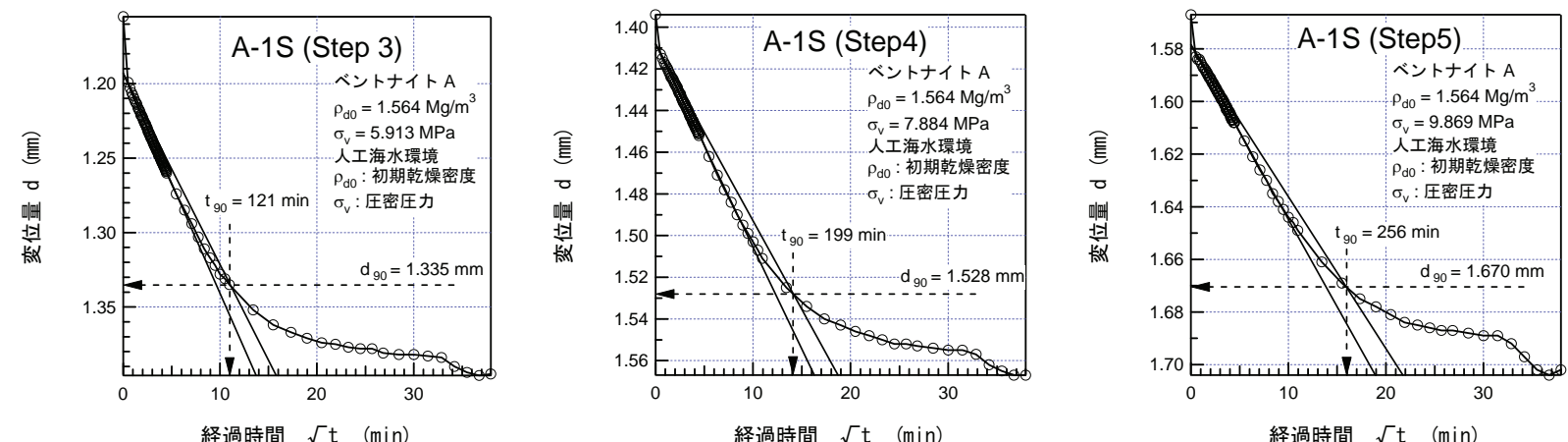

左 : 3 ステップ目, 中央 : 4 ステップ目, 右 : 5 ステップ目

図-10 試験条件 A-1S における圧密変位量と経過時間の関係

表-10 試験条件 A-1S における圧密特性データ

\begin{tabular}{|c|c|c|c|c|c|c|c|}
\hline $\begin{array}{c}\text { 試験条 } \\
\text { 件 }\end{array}$ & $\begin{array}{c}\text { 圧密 } \\
\text { ステップ }\end{array}$ & $\begin{array}{c}\text { 圧密圧力 } \\
(\mathrm{MPa})\end{array}$ & $\begin{array}{c}\text { 圧密量 } \\
(\mathrm{mm})\end{array}$ & $\begin{array}{c}\text { 乾燥密度 } \\
\left(\mathrm{Mg} / \mathrm{m}^{3}\right)\end{array}$ & $\begin{array}{c}\text { 圧密係数 } \\
\left(\mathrm{cm}^{2} / \mathrm{day}\right)\end{array}$ & $\begin{array}{c}\text { 体積圧縮係数 } \\
\left(\mathrm{m}^{2} / \mathrm{kPa}\right)\end{array}$ & $\begin{array}{c}\text { 透水係数 } \\
(\mathrm{m} / \mathrm{sec})\end{array}$ \\
\hline \multirow{3}{*}{$\mathrm{A}-1 \mathrm{~S}$} & 3 & 5.913 & 0.240 & 1.797 & 1.859 & $1.410 \times 10^{-5}$ & $2.978 \times 10^{-13}$ \\
\cline { 2 - 8 } & 4 & 7.884 & 0.172 & 1.841 & 1.077 & $1.042 \times 10^{-5}$ & $1.274 \times 10^{-13}$ \\
\cline { 2 - 8 } & 5 & 9.869 & 0.135 & 1.875 & 0.807 & $8.268 \times 10^{-6}$ & $7.574 \times 10^{-14}$ \\
\hline
\end{tabular}


験方法によれば良好に, $t_{90}$ や $d_{90}$ の值が求められるこ とが分かる。これらの圧密変位量と経過時間の関係 から求められる圧密特性データの例として, 表-10 に試験条件A-1Sのデータを示す，なお，表-10中の 乾燥密度も, 各圧密ステップにおける乾燥密度の平 均值である。

図-11 は，同椂にして実施した表-9 に示した人工 海水環境下における各種ベントナイトの高圧圧密試 験より算出した透水係数の全データを乾燥密度との 関係で整理した図である。ここで述べる乾燥密度も， 各圧密ステップにおける乾燥密度の平均值である. この図から次のことが明らかになった。すなおち，

1） ベントナイト A（Na 型, クニゲル V1）では, 乾燥密度が $1.9 \sim 2.1 \mathrm{Mg} / \mathrm{m}^{3}$ において, 人工海水 環境下の透水係数は蒸留水環境の場合と大きく 差異はないと考えられる。一方, 乾燥密度がお およそ $1.9 \mathrm{Mg} / \mathrm{m}^{3}$ 以下において，人工海水環境下 における透水係数が蒸留水環境の場合と比べ, 高くなる傾向を示寸. 乾燥密度が $1.6 \mathrm{Mg} / \mathrm{m}^{3}$ 付近
では，人工海水環境下における透水係数は，蒸 留水環境の場合の 2～5 倍程度, 高くなるものと 思われる。

2) ベントナイト B ( $\mathrm{Na}$ 型, ボルクレイ $)$ において は乾燥密度がおおよそ $1.6 \mathrm{Mg} / \mathrm{m}^{3}$ 以上であれば, 人工海水環境下の透水係数は蒸留水環境の場合 とほぼ同程度と考えられる。一方, 乾燥密度が おおよそ $1.6 \mathrm{Mg} / \mathrm{m}^{3}$ 以下になると人工海水環境下 における透水係数は蒸留水環境と比べて, 顕著 に高くなることが認められる。

3) ベントナイト C (Ca 型, クニボンド) において は，乾燥密度が $1.33 \sim 1.47 \mathrm{Mg} / \mathrm{m}^{3}$ の範囲では， 人工海水環境および蒸留水環境の透水係数には 大きな差異は認められなかった。

4) ベントナイト $\mathrm{E}$ ( $\mathrm{Na}$ 型, MX-80) においては, 乾燥密度 $1.7 \mathrm{Mg} / \mathrm{m}^{3}$ 以上では, 人工海水環境下の 透水係数は蒸留水環境の場合とほぼ同程度であ る。しかし, 乾燥密度が $1.7 \mathrm{Mg} / \mathrm{m}^{3}$ 以下になると 人工海水環境下における透水係数は蒸留水環境
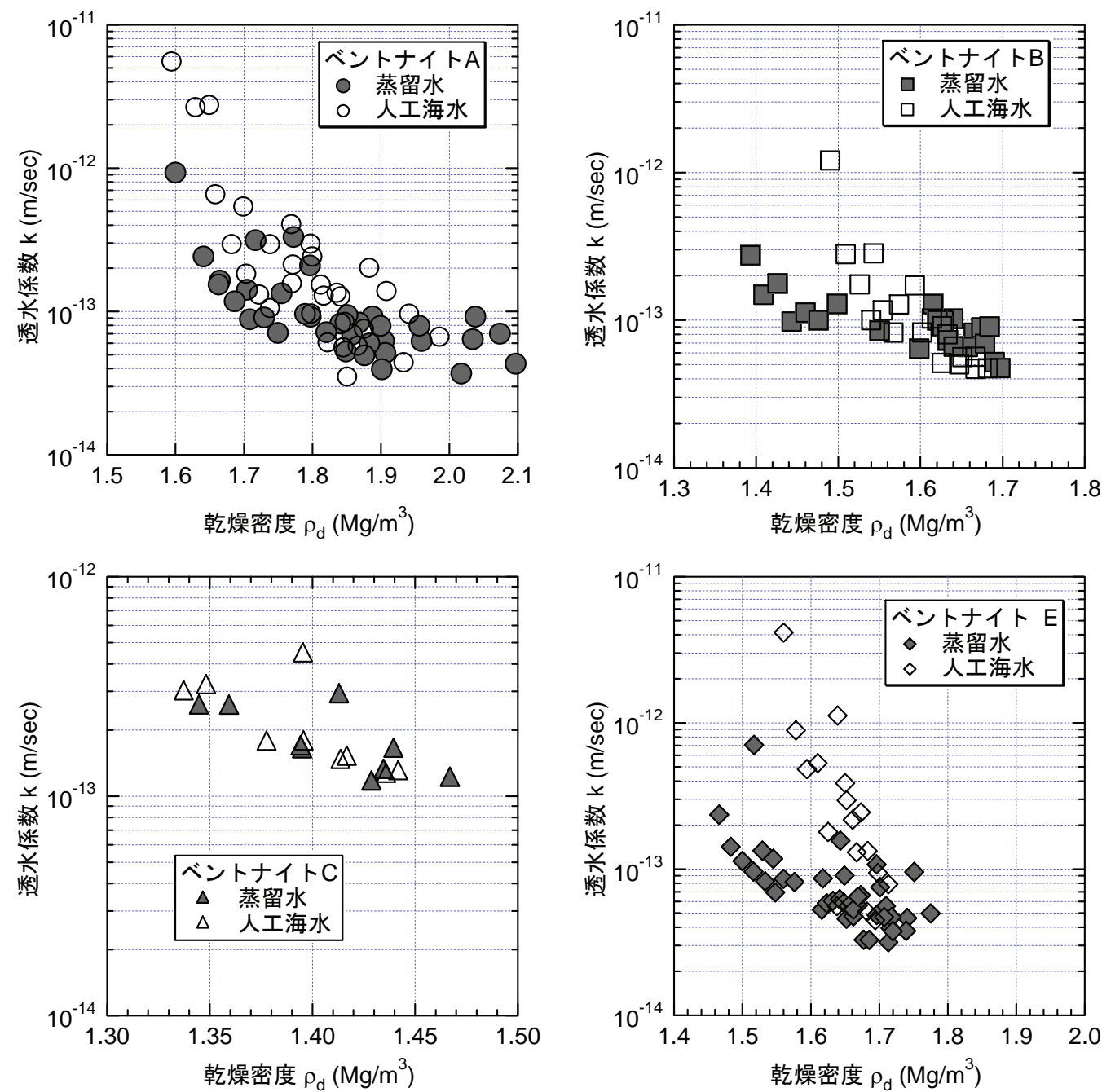

図-11 人工海水環境および蒸留水環境におけるべントナイト $\mathrm{A}, \mathrm{B}, \mathrm{C}, \mathrm{E}$ の透水係数の比較 


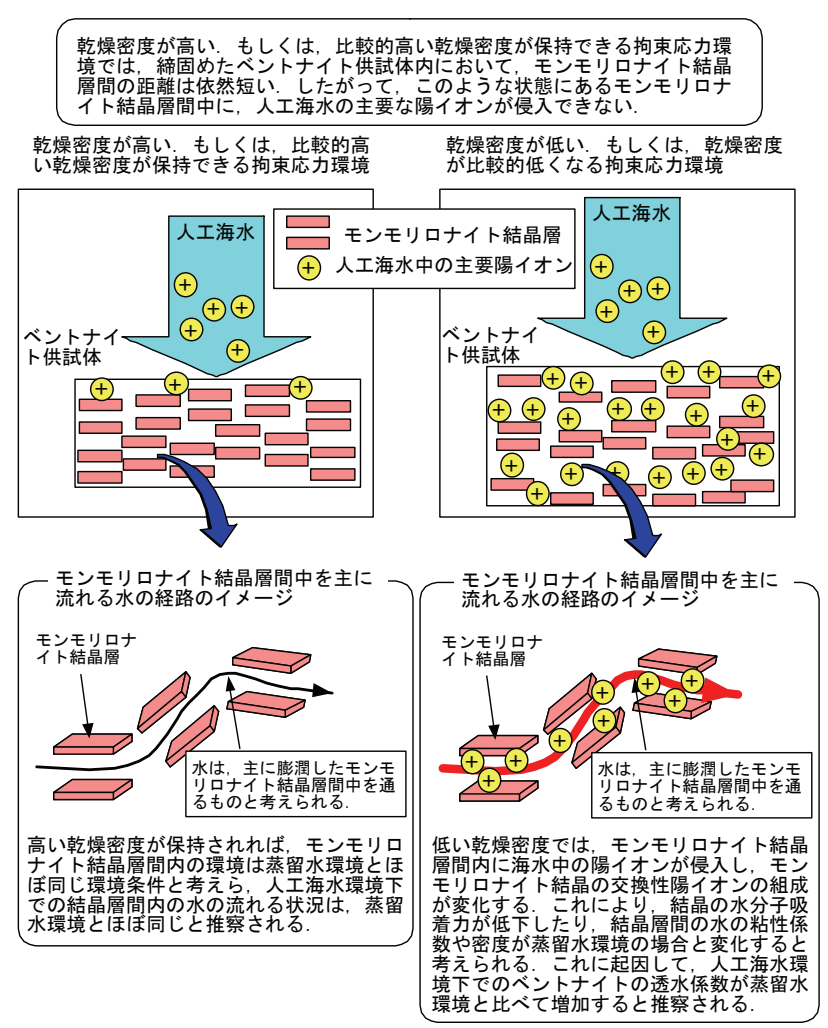

図-12 モンモリロナイト結晶層の濾過機能に基づくベン トナイトの透水係数に及ぼす人工海水の影響入力 ニズムの模式図

と比べて顕著に高くなる.

上述の各種ベントナイトの透水係数に対する人工 海水の影響について次のように考察できる。ベント ナイトの透水係数が他の粘土材料と比べて低いこと の一因として，ベントナイト中の膨潤性粘土鉱物で あるモンモリロナイトが膨潤変形することにより心゙ ントナイト中の水みちとなる間隙を充填することが

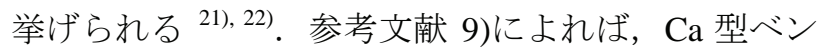
トナイトであるベントナイト C の膨潤圧・膨潤変形 特性は人工海水の影響を受けにくいことが報告され ている。したがって，Ca 型のベントナイト C の場 合，人工海水環境および蒸留水環境において，ベン トナイト中の間隙の充填程度はほぼ同じ状況と推察 されるため，上述の 3)で述べたように，Ca 型ベン トナイト Cの透水係数に対する人工海水の影響は小 さいと考えられる.

それに対して，参考文献 9)によれば $\mathrm{Na}$ 型のベン トナイト $\mathrm{A}, \mathrm{B}$ および $\mathrm{E}$ の場合, 人工海水環境下に おいて，鉛直圧 $1000 \mathrm{kPa}$ の拘束圧条件下の膨潤変形 特性が低下寸ることが報告されている。また，その 影響は, 乾燥密度の増加に伴い小さくなる傾向があ ると報告されている ${ }^{9)}$. このことから，ベントナイ ト $\mathrm{A}, \mathrm{B}$ および $\mathrm{E}$ の場合，上述の 1)，2)および 4)に 述べるように, 乾燥密度が比較的高い範囲において,
人工海水環境下の透水係数は蒸留水環境と比べて同 程度になったものと考えられる，著者らは，参考文 献 11), 12)において, 実験的な調查を通じて, ベン トナイトを高い乾燥密度に締固めることにより，海 水中の陽イオンの供試体中への侵入を低下させるこ とが可能になると推察した。 そして, 海水中の陽イ オンが供試体中に侵入しにくくなる原因の一つとし て, ベントナイト中のモンモリロナイト結晶層によ る海水中の陽イオンの濾過を挙げている。この推察 に基づいて, 本研究の各種ベントナイトの透水係数 に及ぼす人工海水の影響も，図-12 に示すように， ベントナイト供試体中への海水中の陽イオンの侵入 ／濾過メカニズムの観点から考察できる。すなわち, モンモリロナイト結晶層間距離が短く保持される高 い乾燥密度, もしくは, 比較的高い乾燥密度が保持 できる拘束応力環境が維持される場合に，モンモリ ロナイト結晶層間中に海水中の陽イオンの侵入が困 難となり，モンモリロナイト結晶層間内の水の流れ 場は, 蒸留水環境のそれとほぼ同じ状態になると予 想される．参考文献 21), 22)で論じたように，ベン トナイトの透水係数がモンモリロナイトの結晶層間 を主に流れる水の速度に主に支配されるものと考え られることから， Na 型ベントナイト A， B および $\mathrm{E}$ の場合, 乾燥密度が比較的高い範囲において, 人工 海水環境下の透水係数は蒸留水環境と比べて同程度 になったものと推察できる.

以上の考察から，低透水性の観点から海水の影響 を受けにくいベントナイトの種類や緩衝材の仕様と して，次のように考えられる．才なわち，

1） ベントナイト A（Na 型，クニゲル V1）を用い た緩衝材の場合，乾燥密度がおおよそ $1.9 \mathrm{Mg} / \mathrm{m}^{3}$ 以上を保持できる材料仕様および処分孔内の応 力条件であれば，海水の影響は小さいと考えら れ，陸水環境を想定した緩衝材の低透水性とほ ぼ同程度の性能が発揮できると予想される。

2) ベントナイト B ( $\mathrm{Na}$ 型, ボルクレイ) を用いた 緩衝材の場合, 乾燥密度がおおよそ $1.6 \mathrm{Mg} / \mathrm{m}^{3}$ 以 上を保持できる材料仕様および処分孔内の応力 条件であれば，海水の影響は小さいと考えられ， 陸水環境を想定した緩衝材の低透水性とほぼ同 程度の性能が発揮できると予想される。

3）ベントナイト C (Ca 型, クニボンド) を用いた 緩衝材の場合，海水の影響は小さいと考えられ， 陸水環境を想定した低透水性とほぼ同程度の性 能が発揮できると予想される.

4) ベントナイト E（Na 型，MX-80）を用いた緩衝 材の場合, 乾燥密度 $1.7 \mathrm{Mg} / \mathrm{m}^{3}$ 以上を保持できる 
材料仕様および処分孔内の応力条件であれば, 海水の影響は小さいと考えられ，陸水環境を想 定した低透水性とほぼ同程度の性能が発揮でき ると予想される。

本研究では, 参考文献 18)で提案した $\sqrt{t}$ 法に準拠 した方法により, ベントナイトの透水係数を算出し たが，今後は $\log (\mathrm{t})$ 法などの適用も検討寸る必要が ある、また，図-12 に提示したモンモリロナイト結 晶層の濾過機能については, 参考文献 21), 22)で提 案した「ベントナイト系緩衝材・埋戻し材の透水係 数理論評価式」を構成するモンモリロナイト結晶層 間距離算出式による理論的検討も可能である. 以上 の事項は今後の課題であり, 引き続き研究を進め発 表する予定である.

\section{5. 結論}

本研究では，蒸留水環境下での各種ベントナイト の高圧圧密試験および人工海水環境下における各種 ベントナイトの高圧圧密試験を実施した。それらの 試験結果から算出される透水係数を乾燥密度との関 係において整理し, 参考文献18)の既往研究成果も 併用寸ることにより，低透水性の観点から海水の影 響を受けにくいベントナイトの種類と緩衝材の材料 仕様を明らかにした。得られた主な結論は以下の通 りである。

(1) 蒸留水環境下における各種ベントナイトの透水 係数と乾燥密度の関係から，1)ベントナイト A

（Na 型，クニゲル V1）においては, 乾燥密度 が $1.8 \sim 2.1 \mathrm{Mg} / \mathrm{m}^{3}$ の範囲において, $10^{-13} \mathrm{~m} / \mathrm{sec}$ 以 下の透水係数が保持されている. 乾燥密度が $1.8 \mathrm{Mg} / \mathrm{m}^{3}$ よりも低い乾燥密度の範囲で透水係数 が増加しやすい傾向にある，2)ベントナイト B

（Na 型，ボルクレイ）では，乾燥密度が 1.45〜 $1.70 \mathrm{Mg} / \mathrm{m}^{3}$ の範囲において, おおむね $10^{-13} \mathrm{~m} / \mathrm{sec}$ 程度もしくはそれ以下の透水係数が保持されて いる。乾燥密度が $1.45 \mathrm{Mg} / \mathrm{m}^{3}$ よりも低い乾燥密 度の範囲で透水係数がやや増加しやすい傾向に ある，3)ベントナイト E（Na 型, MX-80）にお いては, 乾燥密度が $1.6 \sim 1.8 \mathrm{Mg} / \mathrm{m}^{3}$ の範囲にお いて，おおむね $10^{-13} \mathrm{~m} / \mathrm{sec}$ 程度もしくはそれ以 下の透水係数が保持されている。乾燥密度が $1.6 \mathrm{Mg} / \mathrm{m}^{3}$ よりも低い乾燥密度の範囲で透水係数 が増加しや寸い傾向にある，ことが分かった．

(2) 人工海水環境下における各種ベントナイトの透 水係数と乾燥密度の関係から，1)ベントナイト
A（Na型, クニゲルV1）では, 乾燥密度がおお よそ $1.9 \mathrm{Mg} / \mathrm{m}^{3}$ 以上であれば，人工海水環境下の 透水係数は蒸留水環境の場合と大きく差異はな いと考えられる，2)ベントナイトB（Na型，ボ ルクレイ）においては乾燥密度がおおよそ $1.6 \mathrm{Mg} / \mathrm{m}^{3}$ 以上であれば, 人工海水環境下の透水 係数は蒸留水環境の場合とほぼ同程度と考えら れる，3)ベントナイトC (Ca型, クニボンド) においては, 乾燥密度が1.33〜 $1.47 \mathrm{Mg} / \mathrm{m}^{3}$ の範囲 では, 人工海水環境および蒸留水環境の透水係 数には大きな差異は認められない，4)ベントナ イトE（Na型，MX-80）においては，乾燥密度 $1.7 \mathrm{Mg} / \mathrm{m}^{3}$ 以上では, 人工海水環境下の透水係数 は蒸留水環境の場合とほぼ同程度である, こと が分かった。

（3）上記の(1)と(2)の実験結果・考察に基づき，低透 水性の観点から海水の影響を受けにくいベント ナイトの種類と緩衝材の材料仕様を明らかにし た.

謝辞: 本研究の一部は文部科学省科学研究費基盤 (B)のご援助の下, 実施いたしました。また，本論 文における多くの実験データは, 佛田理恵氏（元茨 城大学大学院生, 現・杤木県庁) が取得したもので ある，関係各位に感謝の意を表します。

\section{参考文献}

1) 核燃料サイクル開発機構：わが国における高レベル 放射性廃棄物地層処分の技術的信頼性一地層処分研 究開発第 2 次取りまとめ一総論レポート, JNC TN1400 99-020, 1999.

2) 核燃料サイクル開発機構：わが国における高レベル 放射性廃棄物地層処分の技術的信頼性一地層処分研 究開発第2次取りまとめ一分冊2地層処分の工学的技 術, JNC TN1400 99-022, 1999.

3)（財）電力中央研究所, 電気事業連合会: 高レベル 放射性廃棄物地層処分の事業化技術, 1999.

4) 核燃料サイクル開発機構幌延深地層研究センター： 幌延深地層研究計画平成13年度調查研究成果報告, JNC TN1400 2002-004, p.18, 2002.

5) Atomic Energy of Canada Limited : Environmental impact statement on the concept for disposal of Canada' s nuclear fuel waste. AECL-10711, COG-93-1, 1994.

6) Swedish Nuclear Fuel and Waste Management Co. : SKB91 Final disposal of spent nuclear fuel. Importance of the bedrock for safety. SKB Technical Report 92-20, 1992.

7) 例えば, Mitchell, J. K. and Soga, K. : Fundamentals of Soil Behavior (Third Edition), John Wiley \& Sons, pp.143- 
171, 2005

8) 小峯秀雄, 直井優, 安原一哉, 村上哲, 百瀬和夫, 坂上武晴 : メスシリンダーを用いたベントナイト系 材料の浸潤・膨潤特性の簡易実験法，土木学会論文 集, No.771/III-68, pp.225-234, 2004.

9) 直井優, 小峯秀雄, 安原一哉, 村上哲, 百瀬和夫, 坂上武晴 : 各種ベントナイト系緩衝材の膨潤特性に 及ぼす人工海水の影響, 土木学会論文集, No.785/III70, pp.39-49, 2005.

10) 田中幸久, 中村邦彦: 海水の濃度と高温履歴がベン トナイトの膨潤特性に及ぼす影響とその評価，土木 学会論文集, No.806/III-73, pp.93-111, 2005.

11) Komine, H., Yasuhara, K. and Murakami, S. : Swelling characteristics of bentonites in artificial seawater, Canadian Geotechnical Journal, Vol. 46(2), pp. 177-189, doi: 10.1139/T08-120, 2009.

12) 小峯秀雄, 安原一哉, 村上哲 : 人工海水環境下にお けるベントナイトの一次元自己シール性, 土木学会 論文集C, Vol. 65, No. 2, pp. 389-400, 2009.

13）田中幸久，長谷川玩磨，中村邦彦：海水の濃度が各 種ベントナイトの透水係数ならびに膨潤圧に及ぼす 影響のモデル化，土木学会論文集C, Vol. 65, No. 1, pp. 66-84, 2009.

14) Shackelford, C. D., Benson, C. H., Katsumi, T., Edil, T. B. and Lin, L. : Evaluating the hydraulic conductivity of GCLs permeated with non-standard liquids, Geotextiles and Geomembranes, Vol. 18, pp. 133-161, 2000.

15) Jo, H. Y., Katsumi, T., Benson, C. H. and Edil, T. B. : Hydraulic conductivity and swelling of nonprehydrated GCLs permeated with single-species salt solutions, Journal of Geotechnical and Geoenvironmental Engineering, American Society of Civil Engineers, Vol. 127, No. 7, pp. 557-567, 2001.

16) Villar, M.V. : Infiltration tests on a granite/bentonite mixture: Influence of water salinity, Applied Clay Science, Vol. 31, pp. 96-109, 2006.

17) Katsumi, T., Ishimori, H., Onikata, M. and Fukagawa, R. : Long-term barrier performance of modified bentonite materials against sodium and calcium permeant solutions, Geotextiles and Geomembranes, Vol. 26, pp. 14-30, 2008.

18) 佛田理恵, 小峯秀雄, 安原一哉, 村上哲: 高圧圧密 試験装置を用いたベントナイトの透水係数算出にお ける試験方法の高度化，土木学会論文集C, Vol. 62, No.3, pp.573-578, 2006.

19）地盤工学会：地盤材料試験の方法と解説一二分冊の1 一, pp.462-499, 2009.

20）小峯秀雄, 緒方信英 : 塑性限界を導入した粘土の締 固め特性の評価法の提案, 土木学会論文集, No.436/III-16, pp.103-110, 1991.

21) Komine, H. : Theoretical equations on hydraulic conductivities of bentonite based buffer and backfill for underground disposal of radioactive wastes, Journal of Geotechnical and Geoenvironmental Engineering, American Society of Civil Engineers (ASCE), Vol. 134, No. 4, pp. 497-508, 2008.

22) Komine, H. : Predicting hydraulic conductivity of sandbentonite mixture backfill before and after swelling deformation for underground disposal of radioactive wastes, Engineering Geology, Vol. 114, pp. 123-134, 2010.

(2010. 8. 12 受付)

\section{HYDRAULIC CONDUCTIVITY OF SOME BENTONITES IN ARTIFICIAL SEAWATER}

\section{Hideo KOMINE, Kazuya YASUHARA and Satoshi MURAKAMI}

A high-level radioactive waste disposal facility might be built in a coastal area in Japan from the viewpoint of feasible transportation of waste. Therefore, it is important to investigate the effects of seawater on a bentonite-based buffer. This study investigated the influence of seawater on hydraulic conductivity of three common sodium-types of bentonite and one calcium-type bentonite by the laboratory experiments. From the results of laboratory experiment, this study discussed the influence of seawater on hydraulic conductivity of bentonites from the viewpoints of kinds of bentonite such as exchangeable-cation type and montmorillonite content and dry density of bentonite-based buffer. 